\title{
WPW症候群の診断と治療
}

\begin{tabular}{|c|c|c|}
\hline 第 2 & 日 & (10月20日） $15: 30-18: 00$ \\
\hline 会 & 場 & メインホール \\
\hline 4 & 長 & 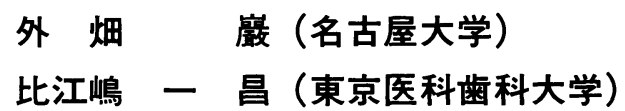 \\
\hline
\end{tabular}

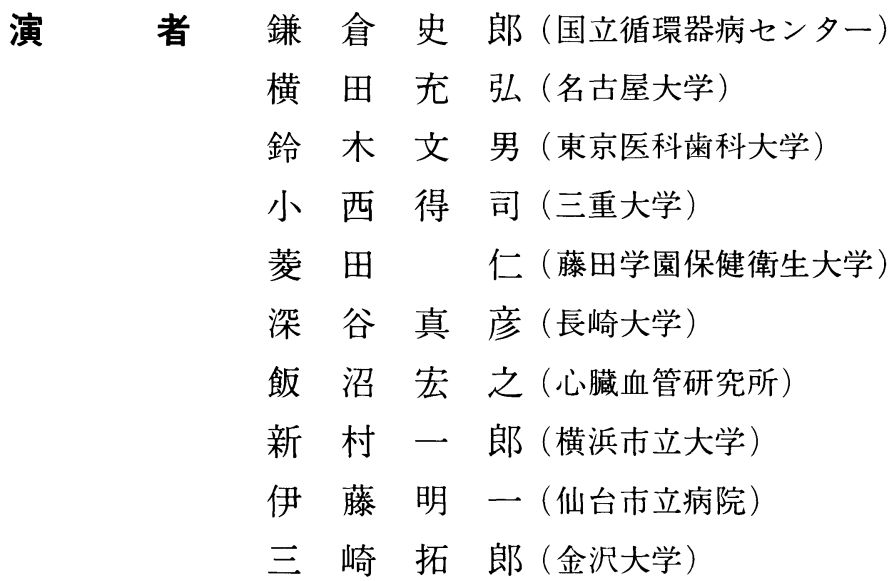

座長のことば

WPW 症候群は古くて新しいテーマである。かつて, ロゼッ夕石の象形文字に譬えられた そのミステリ一性は, 最近の電気生理学的研究の発展により, かなり薄らいではきたが, 完 全にベールを剝がされたとはいえない。かかる理由からか, WPW 症候群は, 最近学会等で しばしば取り上げられているが，いずれもその機序や頻脈性不整脈に対する一般療法が論議 の中心になっている。しかるに, WPW 症候群で最も臨床的意義のあるのは, high risk患者 の早期識別とその対策である。

今回のシンポジウム パートIIでは,このhigh risk患者にまつわる問題点, 即ち, 自然歴, 診断，治療および管理について，この分野での専門家に講演・討議をして頂く予定である。 なお，当日は時間の許す限り，会場からも質問を受け付けるとのことであるので，活発な討 論が行われ，実りの多いシンポジウムとなることを期待してやまない。 
体表面電位図法

鎌倉史郎

国立循環器病センター内科心臟部門

S. Kamakura

National Cardiovascular Center, Division of Cardiology

WPW症候群の副伝導路(AP)の存在部位推定にお いて, 体表面電位図法は標準12誘学心電図やベク トル心電図法に比べ,より詳細な局所的情報を提 供しうる。今回我々は体表面電位図法で得られた AP推定部位と, 観血的方法で求めたAP存在部位と を対比し，体表面電位目法の有用性と限界とを考察した。

\section{1. 対象と方法}

WPW症侯群 41 例(男23例, 女18例), 潜在性WPW症候 群 42 例 (男26例, 女16例) : 全例カテーテルによる電気生理 学的検査, あるいは術中の心表面マッピングによ りAPの存在部位を確認した。

(1) WPW症候群

APの存在部位を房室弁輪部左室側の前䇒, 側壁, 後壁の 3 力所と, 右室側の前塈, 侧蟋, 後壁の3 力所, 及び前部中隔, 後部中隔の 2 力所, 計 8 力 所に区画して分類し, 体表面電位図から得られる 諸指標と対比検討した。体表面電位困はHPM5100Aを用 い, 胸部 87点より早期興死を伴う洞調律時に,サン プリング間隔 $4 \mathrm{msec} て ゙$ 記録した。

（2）潜在性 WPW 症候群

房室弁輪部上の左右心房の各部位より電気刺数 を加え，P波の体表面電位図を記録し，刺部位 により一定の電位分布が出現するととを確かめ, ついで刺敏部位と，陰性 P 波の電位が最大值を示 す体表面上の誘導部位との相関を求めた。との結 果に基さ，体表面上で 5 力所の誘荨部位を選択し， 回㷌性頻拍中に通常の心電計を用いて単極誘荅心 電図を記録した後, 逆行性 $\mathrm{P}$ 波の電位を比較して AP 存在部位との関連を検討した。

\section{2. 結果 \\ (1) WPW症候群}

i）電位図上, QRS初期に極小の電位が渐次深 まり，一0.15 mVを超えた時点での極小の位置加 $\mathrm{AP}$ 存 在部位とょく対応し, 以下の位置的関係を認めた。 左室前暨AP一背部上方; 左室側暨AP-背部中央; 左
室後壁AP-背部下方; 後部中隔AP-右倒胸部下方; 右室後壁 $\mathrm{AP}$-右前胸部下方; 右室倒壁AP-右前胸部

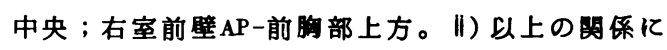
基ついて，41例中 36 例でAP 部位の推定が可能であ った。iii) 残り 5 例は上記対応関保と一致せず， 接する部位がAP部位と判定された。IV）QRS 開始

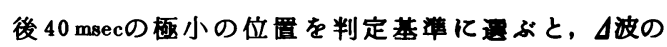
小さい症例が正常层導路由来の心室興㲤の影管を 受けるため，41例中11例でAP部位を推定し得なかった。 （2）潜在性 WPW 症候群

1）房室弁陯部上の心房の各刺激部位と, 陰性 P 波の電位が最大值を示す体表面上の誘㱏部位と の間に次の様な対応を認めた。左房前塈, 㑡壁刺 数一左前胸部上方; 左房後壁, 右房後㲥, 後部心 房中隔刺激一前胸部中央下方; 右房前暨, 前部心 房中隔刺数一前胸部中央上方; 右房側暨刺一右 前胸部下方。ii）上記の関係に基つさ, 回版性頻 拍中に左右の前胸部上方 (左右の第 2 肋間前腋窝 線上) と, 前胸部中央上方（第 3 肋間胸骨上）と, 前胸部中央下方 (心窝部下方), 及び右前胸部下 方 (右季肋部前腋窝線上) の計 5 力所で単極脬迋 心電図を記録し，42例中80例で逆行性P波を同定し 得た。iii）頻拍中の陰性 P 波が最大西位を示す质

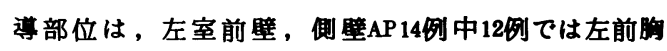
部上方誘導であり, 左室後䇒AP 9例中 8例, 右室後䇒, 後部中隔AP4例中3例では前胸部中央下方誘蓄であ り, 右室前壁, 前部中隔AP 8例中8例では前胸部中

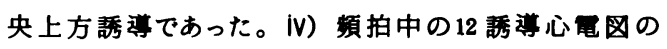
$\mathrm{P}$ 波の極性からも，AP部位の推定が可能であった。

\section{3. 総括}

（1）WPW症侯群では，体表面電位図上 QRS 初期 に電位がー0.15 mVを超えた時点での原小の位置により, 副云学路部位を詳細に推定しうる。(2)潜在性 WPW 症候群では, 回㷌性須拍中の体表面心電図にわい て, 逆行性の陰性 P 波の兆位が最大となる誘学部位 を検討するととにより, 副层竞路部位の推定が可能である。 
WPW症候群における心室グラディエント解析の臨床的意義

横田充弘小出正文外畑踇

名古屋大学第一内科

M. Yokota, M. Koide, I. Sotobata

1 st Dept. of Internal Med., Nagoya Univ. School of Med.

ST間部およびT波は心空筋再分極相につ いて診断的意義の大きな情報を提供する。し かし W PW 症候群, 脚プロックては心室内興卒 伝播過程の異常飞起因する二次性 ST-T变化 が㻐らため, たとえ心室筋細胞の再分極相変 化飞原因する一次性 ST - T 变化が存在して。 その心電図診断は困難または不可能である とが多い。心室グラディエント（VG）の解析は 二次性 ST-T変化火覆われた一次性 $\mathrm{ST}-\mathrm{T}$ 変 化の検出に有力な 1 手段であるとされている。

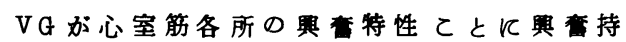
続時間の差飞上り決定され，心室脱分極順序 飞依存しないてと（VGの恒常性）はWilson らにより指摘されたが，その妥当性を検討し た臨床報告は比较的少なく，しかる一致した 見解が得られていない。すし V Gの恒常性が 臨林的見地より妥当と考えられるならば，正 常人を対象として作成された VG診断基準を そのまま心室内興落僠異常群飞適用するこ とがでる。またたと的の恒常性が妥当 てないとしても，心室内興者伝播過程の変化 飞随伴するVG偏位について規則性が見い出 されれば，その規則性に従って正常診断基準 を修正して用いることるでよう。

本報告の目的は間歇性 W PW症候群を対象と して, 空間VGの恒常性を推計学的および臨 床的見地より検討するととると, VGの解析 が W PW症候群に合併した陳旧心筋梗塞の診断 に有用てあるか否かを検討することである。

1. 安静時間歇性 W PW 型心電図を示した 12 例を対象として空間 VGの恒常性を検討した。 各症例 W WW 型, 正常型の両空間 VG平均へ クトルの差を検討した結果, 非定型的 W PW 型 心電図を示した 1 例を除を，推計学的には全 例飞有意差を認めた。したがって少なくとる 間歇性 W PW 症候群ては空間 VGの恒常性は成
立しないと結論される。しかし対象各例にお ける個々の誘導の正常型, WPW 型 VGの平均 值は近似し, 两者間の差(䋓対値) は平均 8.97

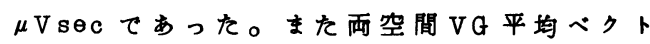
几の極座磦成分については，大きさては平均 $7.08 \mu \mathrm{V} \mathrm{sec}$, 方位角ては平均 6.90 , 仰角ては 平均 5.80 の差を認めたにすをなかった。 $\triangle A Q R S$ と $\triangle \mathrm{AT}$ との間には各誘導とす高度に 有意な負の相関が存在 L, VGの恒常性を仮 定した直線に比較的よく一致した。空間 V G の正常箐囲が，性，年令およひ心拍数を考虑 してるかなり広いことを考えると，臨床的に は空間 VGの恒常性は成立するとして大きな 俱謬はないと思われる。

2. $\mathrm{A}$ 型 W PW 症候群 0 钼察治餈中凡前壁心筋 梗塞を発症した 1 症例につんて, 梗塞発症前 後の空間 VGを比較検討した。梗塞前の正常 型, WPW 型の而空間 V G はをさ, 方向とす 比較的近似していた。それに比し梗塞後の空 間 VGは明らかにその大をさを娍し，方向す 梗塞前飞比し著明飞右後下方へ偏位した。一 般飞陳旧心筋梗塞患者ては空間 VGの大むさ 江健常人に比し娍少し，その方向は梗塞巣加 ら遠さかる方向に向かう。したがって前壁梗 塞は右後下方を，下壁梗塞は上方を向くと考 えられており，本症例て。同椂の傾向が認め られた。実際にW PW症候群の梗塞合併前後の 空間 VGを検討した報告は柾めて少ないが， 今回の結果上り, W PW症候群に心筋梗塞驾合 併した場合，その一次性 ST-T变化の検出に 空間 VGの解析が有用と考えられた。 
経食道心房ペーシンク法

鈴木文男

東京医科歯科大学第一内科

F. Suzuk i

The 1st Department of Internal Medicine, School of Medicine, Tokyo Medical and Dental University.

演者らはすてに第47回ならびに48回の日本循渨 器学会総会におらて, 経食道心房べーシング法 (以 下食道ベーシンク法)の臨床応用の可能性につい て報告してきたが、本シンボシウムにおいては， W P W 症候群の診断（・治療）といら観点から食 道べーシンク法の有用性と限界につんて検討を加 えたのて報告する。

\section{1. 方法}

電極間距離 $1 \mathrm{~cm} \oslash 6$ 極 $10 \mathrm{~F}$ カテーテル (USVP 社製)を経基ないし経口的に食道に指入し，先端 電極と 4 番目の電極て双極食道電位を記録してそ の電位が最大振幅を示す位置にカテーテル電極を 固定し、てれらの双極から電気刺敫を行った。ブ ロクラム刺敫置としては, 日本電気三栄社製 3 F-46ならびに3F-51の複合電気刺激装を用い， 最大出力 $50 \mathrm{~mA} の$ 同社製 5361 型アインレータを介し て幅 $15 \mathrm{msec}$, 強さ10〜15 mA（まれに20 mA）の矩形 波を与えて食道べーシンクを行った。食道べーシ ング法に上る左房刺激の方法としては早期刺激法 と頻回刺激法（70２60/分）を行い，Kent束お上 び房室伝埒系の伝導能の評価を行った。一部の症 例ては $300 \sim 400 /$ 分 $\times 30 \sim 50$ 拍の刺激にて心房細 動・粗動の誘発を試みた。更に頻拍例においては。 静注ならびに経口の抗不整脈荗の萝効評価を行った。

\section{2. 結果お上び考察}

W P W 症候群に対し食道べーシング法を行らて とに上って,以下に述へろ椂な成績が得られた。 (1) Kent 束の有奻不応期の測定

基本刺激周期 400 800 msec 飞おらて, Kent 束 の有効不応期 (ERP) の測定が多くの例て可能て あった。测定された ERPは 240〜380 msecであった。 (2)頉回刺激法几上るKent束の伝導能の評価

本法によりKent束を経由するインパルスの房室伝 導能を評価し, Kent 束の block rateを求めた。そ の結果, block rateは160〜260/分てあった。一
部の症例では，Kent束のブロック後す房室結節を 経由する1:1の房室伝導が認められた。

(3) “上室”性頉拍の弧発，診断ならびに治療 早期刺激法ならびに頻回刺激法に上り，素因の ある患者ては房室リエントリー性頻拍が脬発され た。誘発された覑拍中，食道誘導に上る心房エコ 一波を記録するてとにょり，心房エコ一波と心室 波との時相関係から, 房室結節リエントリー性頻 拍との鑑別が可能でった。更に，食道べーシン ク法に上る頻拍誘発が可能な例においては，静注 ならびに経口の抗不整脈郕に対する，短期的なら びに長期的な電気生理学的薬効評価が可能ですった。 (4)顕性 W PW 症侯群における心房細動・粗動の誘発

食道ベーシンク法ても一部の例て心房細動・粗 動が話発され，その際の最每 R-R間隔を測定して， Kent 束のERPとの相関を検討するととが可能てあ った。

(5)非定型的 W P W 症候群の診断

$P R$ 間隔が 0.12 秒以上て小さんム波を有する非 定型的 W P W 症候群に対し，食道ベーシング上 る早期刺激法と頻回刺激法を併用するととに上り。 Kent 束型か Mahaim束型かの别が可能てあった。 (6)左房(冠静脈洞) ペーシンクの代用

観血的心炡カテーテル検査におらても，カテー テル電極を冠静脈洞に挿入することは時として困 難てある。この際, 冠静脈洞へーシンクの代わり に食道べーシンクを行えば左房べーシンクを行っ たととになり，、波が出現しなければ，この所見 は左心型の潜在性 W P W 症候群の診断基準の1 として採用しらろてあるら。

以上，食道べーシンク法の有用性をあげた。そ れらの5ち, 本法は特几電気生理学的な薬奻評価 に最も有用と考元られた。 
ゲート心プールシンチを用いた W P W 症候群の診断

小西得司, 山室匡史, 市川毅彦, 中野越, 竹沢英郎

三重大学第一内科

T. Konishi, M. Yamamuro, T. Ichikawa, T. Nakano, H. Takezawa

First Dept. of Internal Med. Mie University

ゲート心プールシンチグラフィー (GBPS) は， 従来非観血的な心機能及び心室局所壁運動の評価 に用いられてきた。てのR.I. 画像の functional image の 1 つとしての phase imageは, 局所心室 の収縮伝搬を明確に表示し得ることから, 本法を WPW 症侯群に応用し, 異常早期収宿開始部位す なわち副伝導路の存在部位の検出を行った。

\section{1. 対象及び方法}

対象は標準 12 誘導心電図にて診断されたWPW 症候群 25 例（A 型 13 例，B型 12 例）である。GBPS 施行時心電図上デルタ波を認めたのは22例（A 型 13 例，B型 9 例）であった。本症と対比するため 正常 20 例, 合併症を有しない脚ブロック 8 例, 右 室ペーシング 5 例も R.I. 検查を施行した。GBPS は Tc- $99 \mathrm{~m} 25 \mathrm{mCi}$ を体内赤血球標識後, 1 心拍を 28 分割するマルチゲート法にて左前斜位, 右前斜位, 左側面の 3 方向から撮像した。一方プロカインア ミド投与した WPW 症候群 15 例中デルタ波の消失し た 13 例において同様に撮像を絽り返し行った。他 方 6 例のWPW症候群において対向回転型ガンマ カメラにて断首心プール像をあ検討した。phase

Spread of Contraction in Normal Heart

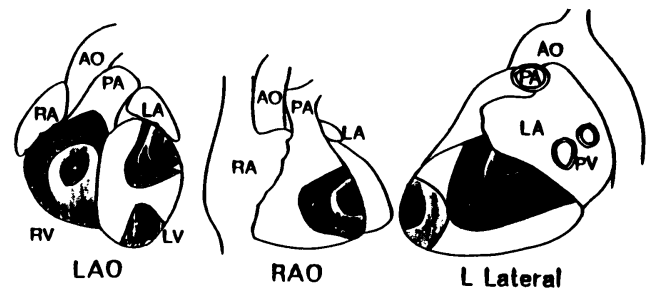

image は得られた $64 \times 64$ matrix の各 matrix の time activity curveをフーリエ級数基本周波で近似し， その位相角を示す functional image であるが, 位 相角の早い部位が早期収縮を表現している。各方 向からの phase imageにより両心室の収縮パター ンを立体的に判定し, WPW 症候群でみられる収 縮異常を検討した。

\section{2. 結果ならびに考察}

正常例の右室収宿パターンは, 前壁中央心尖部 よりから収縮が開始し心尖部及び心基部に向い, 右室流出路に終っていた（図1）。一方左室は前 壁心基部, 前壁中央部, 下壁, 後側壁等の幾つか の部位より収縮が開始しそれぞれ融合し終了して いた。乙れは E picardial mappingの結果とよく一 致した。WPW 症候群 B 型では, 全例において正 常では認めない右室心基部心房直下より収縮が開 始し,心尖部に向い広かっていた。プロカイアミ ド投与によるデル夕波消失例では，乙の異常収縮 が消失した。他方 WPW 症候群 A 型では, 左室心 基部心房直下に明確な異常早期収縮開始を 13 例中 12 例に認めた。B型と同様に薬物又は手術におい てデルタ波消失例で, この異常収縮は消失した。 興味がたれたのは, $\mathrm{A}$ 型 3 例において右室心基 部にも異常早期収縮部位を認め, 全例プロカイン アミド投与により消失し複数の副伝導路の存在か 考えられた。断層心プール像の phase image では 両心室を分離しょより明確に異常部を検出し得た。 Phase image において, 心室の興古様式と収箱 様式がく一致していることが知られているか， WPW 症候群においては, 副伝導路の存在部位を 明確にするだけではなく, 潜存性の副伝導路の存 在をあ指摘し得る。すなわち手術例において, 術 前検查に最も有用な非観血的検查法の1つではな いかと考えられる。 
W P W 症候群早期興奮部位の心エコー眓による診断

\author{
菱田上, 坂部慶幸, 桜井充 \\ 藤田学園保健衛生大学内科 \\ Hitoshi Hishida, Yoshiyuki Sakabe, Mitsuru Sakurai \\ Dept. of Internal Med., Fujita-Gakuen Health Univ. Sch. of Med.
}

W P W 症候群にわいては心室内興奮云導異常が 存在するので, 興夽を trigger として起る収縮 の順序も異常となる。かかる心室収縮様式の異常 は心エコー困の出現により極めて容易に且つ詳細 に把握するととが可能となった。そとで，心エコ 一四により WPW 症候群の心収縮様式の異常を捉 えて早期興奮部位の診断を行なうことの意義につ き報告する。

1) WPW 症候群の Mモード心エコー困所見

左室後壁の動き：収縮期前方運動が, 正常より も早期に（１音よりも前に）始まり，早期に（I 音よりも前に）peakに達し後方に戻り始める。そ れに伴ない，収縮期前方運動開始直後に小さな前 方凸の山ないし step形成を見る。とれは早期興奮 部位が, 一旦収縮によって前方に動くが, 左室の 残りの心筋も収縮して等容収縮期に入ると押し戻 される為と思われる。収縮期前方運動の peakは二 峰性を示すととが多いが, 早期に弛爰した早期興 奮部位が内任により一時的に外方に脚隆する為と 思われる。かかる所見は左室後壁の早期興奮を示 すと考えられる。

心室中隔の動き：収縮期後方運動の開始が正常 よりも早い( I 音より前)。しかし左室の他の部 分に興奮が拡がると押し戻され小さな後方凸の山 を形成する。駆出期には正常とは逆に前方に変位 するととが多い(奇異性運動)。乙れは右室が左 室より早く興奮するととを示すと考えられる。

右室前壁の動き：左室後壁の異常運動とmirror patternをなす所見を認める。即ち, 収縮期後方 運動がI音より前に始まり，正常より早く【音よ り前に後方への peakを形成する。とれらは右室前 壁の早期興奮を示す所見と思われる。

\section{2) 早期興逳部位の診断}

上記 $M$ モード所見の有無により診断するが，断 層心エコー四を併用してビーム方向を確認しなが

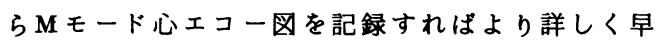
期興奮部位を位置づけうる。同様のととは $\mathbf{M} モ-$
ド・スキャンを行っても可能である。但し，超音 波ビームと心室壁とが平行となる部位の動きは検 出困難である。

3) 他の検査法との比較

(1) 心電図分類との対比

Rosenbaum らの分類のA型，B型はそれぞれ左 室, 右室に早期興奮部位があるとされるが,心工 コー図所見と対比するとA 型に於ては確かに左室 後壁に早期興奞による異常運動を認めるが, B 型 の左室後壁及び心室中隔エコー・パターンは様々 であり， B 型は種々の早期興奮部位を含むと考え られる。しかし, 右室前壁の早期興舊エコー・パ ターンが約半数に認められ， B 型の多くは右室前 壁近くに早期興奮部位があるととが推察される。

(2) ベクトル心電図との対比

早期興奞部位の診断にはやはりデルタ波に注目 すべきであろう。外畑らは水平面デルタ・ベクト ルに基づき $\alpha, \beta, \gamma, \varepsilon$ 型に分類した。左室後 壁及び心室中隔エコーの早期興奮パターンの有無 と対比すると， $\alpha$ 型は殆んどの例で左室後壁の早 期興奮エコー・パターンの存在を認め左室後壁周 刃の早期興奮を示すと考えられた。及型は殆んど の例で心室中隔の早期興奮エコー・パターンを認 め, 右室の早期興奞を示すと思われた。 $r$ 型は症 例により様々であったが, 左室後壁の早期興奮パ ターンを示す例が約半数あり，その近辺に早期興 奞が存在するととが多いと思われた。即ち、デル タ・ベクトルによる分類はエコ一所見と更によく - 一致した。

（3）体表面電位図，心プールシンチphase image 所見とも対比する。

以上の如く，WPW 症候群における心室収縮様

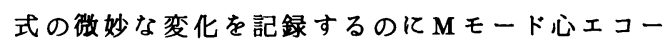
図は適しており，それに基つき正確に非観血的に 早期興奮部位を决めうる筈であるが, 適切な角度 でビームを投入しうる部位が限られる等の記録困 難という制約が難点である。 
WPW症候群におけるhigh risk患者の診断と対策

深谷䘮彦，木谷文博

長崎大学第 3 内科

M.Fukatani, F.Kiya

The Third Dept. of Interna1 Med., Nagasaki Univ.,

School of Med.

WPW症候群のなかで発作性心房細動(Paf)を伴 う例には急死のriskをもつものがある。今回は high risk患者として Paf 例を主な対象とし, その 臨床像, 電気生理学的検査成績などの検討を行っ た。

\section{対象および方法}

対象は臨床心臓電気生理検査( EPS)による検討 を行ったWPW 症候群103例 ( A 型55, B 型48例。男 64 , 女39例。年令 $6 \sim 76$, 平均 $31 \pm 13$ 歳)である。 この103例中 Paf 群は14例 ( A 型 8, B 型6 例。男 13 ,女 1 例。年令 $17 \sim 57$, 平均 $35 \pm 9$ 歳) で, 対 照群（房室回帰性頻拍例十頻拍歴のない例）が 89 例である。なお，Paf 群にはEPSを行わなかった Paf 例 9 例を合わせて臨床像や心電図所見の検討 を行った。EPSは, 通常心電図および心腔内電位 （高位右房，冠静脈洞内左房，ヒス束，右室）の 記録下に右房，左房，右室から連続剌激および 2 つ以上の基本周期での期外刺激法を行い，正およ び逆伝導における副伝導路 (AP)や房室結節の有 効不応期 (ERP)の測定などを行った。Procainamide は600 mgを33例に， atropine は $1 \mathrm{mg}$ を30例に静注し て薬物前と同様の検査を行った。

\section{結 果}

1.Paf 群の臨床症状と心電図所見

(1)臨床症状：EPSを行った14例および行わなか った 9 例を合わせた 23 例中，発作時失神歴(十)が 4 例(うち 1 例は急死)，めまい(代 4 例であった。 また，低血圧をきたした例が 4 例，胸痛や胸部圧 迫感(十)が14例であった。(2)心電困所見：発作時心 電図の最短 $\mathrm{R}-\mathrm{R}$ は 160 〜 $280 \mathrm{msec}$ であったが, 200 $\mathrm{msec}$ 末満が 23 例中 9 例あった。この 9 例中失神(十) が 3 例，めまい(H)が 3 例であった（急死例は 160 $\mathrm{msec}) 。 \mathrm{Paf}$ 時の平均心拍数は毎分 $150 \sim 270$ で, 200 以上が11例あった。QRSはほとんどがWPW型 であった。
2. Paf 群と対照群の臨床電気生理所見

(1)AP の正伝導ERP：Paf 群 14例について各症 例の最短ERP の分布をみると201 225 msec が $21 \%$, $226 \sim 250 \mathrm{msec}$ が $29 \%$ と, $250 \mathrm{msec}$ 以下が合わせて 50 \%を占め, 251 〜 $300 \mathrm{msec}$ が $50 \%$ であった。対照群 についてみると，200msec 以下が $1 \% ， 201 〜 225$ $\mathrm{msec}$ が $3 \%, 226 \sim 250 \mathrm{msec}$ が $25 \%$ で, $250 \mathrm{msec}$ 以 下が合わせて $29 \%$ 占めた。なお，251 300 m sec

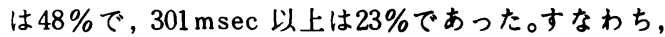
$\mathrm{Paf}$ 群の場合, $250 \mathrm{msec}$ 以下の占める割合が高いと いう結果を得た。Paf 群について臨床症状との烕 係をみると, $250 \mathrm{msec}$ 以下の 7 例中 3 例に失神(H) (うち急死例の ERP は2 $235 \mathrm{msec}$ )，3 例にめまい(+) で, $250 \mathrm{msec}$ 以上の 7 例中では失神(H)1例のみであ つた。(2) Paf 時の最短 $\mathrm{R}-\mathrm{R}$ と AP の最短 $\mathrm{ERP}$ ：両 者は一致せず, $\mathrm{Paf}$ 時の最短R-Rの方が30〜 95， 平均 $60 \mathrm{msec}$ 短かい值を示す例が多かった。(3)AP のERPに対する atropine の影翼：ERPは0〜210 $\mathrm{msec}$ の籍囲で短縮したが, 一部の例を除くと 15 45 , 平均 $27 \mathrm{~m} \mathrm{sec}$ 短縮した。(4)AP のERPに対する procainamide の効果：33例中12例ではAP の正伝 導がブロックされ，21例ではERP が240〜310 (270 $\pm 15) \mathrm{msec}$ か ら $270 \sim 360(300 \pm 25) \mathrm{msec}$ へと平均30 msec 延長した。

\section{総括および考察}

(1)Paf 群のなかで発作時のめまい，失神歴ある 例， Paf 時の最短 R-Rが $200 \mathrm{msec}$ 以下あるいはEPS にて得たAPの正伝導ERP が $250 \mathrm{msec}$ 以下の例は high risk 症例と考えられる。(2)APの正伝学ERP の最短值はPaf 時の最短 R-Rよりも長かったが, atropineにて短縮したので，Paf 時の心西国記録 のない例ではatropine 後の測定値がよりよい指标 になると考えられる。(3)procainamide はAP の正伝 導能を抑制した。high risk例にはこのような薬绪 の長期投与と管理が必要である。 
W P W 症候群の自然歴

飯沼宏之

心臓血管研究所

H. I i numa,

The Cardiovascular Institute
W P W 症候群の心房細動併発率は 10〜20\%程度 といわれでいるが、その中副伝導路不応期短縮例 では心拍数は著増し、ついには心室細動に到る場 合のあることが報告されている。又W P W 症候群 が他の心疾患に合併することもまれならずあるが その合併疾患にて死亡する場合もある。一方この ような例を除けば W P W 症候群の予後は良好とす る意見も多い。即ち、病院を訪れるW P W 症候群 患者は有症のことが多く、W P W 症候群の中でも 比較的重症者が病院に集中する傾向があるので、 病院資料に基づく統計成績は必ずしも正確でない おそれがある。今回、我々は生命保険会社の資料 から、軽症者が比較的に多いと思われる群での、 W P W 症候群の予後を検討する機会を得たので報 告したい。

\section{対象および方法}

調査 I：昭和 44 年 53 年の計 10 年間に某生命保険 会社と契約をかわした 830 万名の中、心電図撮影 者は15 万名あったが、その中W P W 型心電図を呈 した 100 名の契約者（男 90 名、女 10 名、40才以上 83 名)を対象とし、この10 年間における経過契秎 件数 (契䄪件数 $\times$ 有効契約期間) 、実死亡数、死亡 指数（実死亡数/予定死亡数 $\times 100$ ）を求めた。 調査 II：生命保険協会（本邦生命保険会社全 20 社 加盟) 死亡率調査委員会報告では、昭和 42 年 49 年、計 8 年間の心電図識影者は 40 万名あったが、 その中W P W 型心電図を呈した291名を対象とし 上と同様の調査を行った。

結果

調査 1：(1)対象 100 名の中、境界体契的者（死亡 指数 130 末满) 4 名、標準下体契約者 (死亡指数 130 以上 500 末满) 96 名であった。(2) 10 年間の経 過契䄪件数は 320.1 件であった( 経過年数 5 年： 28 件、経過年数 10 年: 2 件)。(3)各契約者の年令、 条件、及び経過年数から推定された予定死亡数は 1.2568 であった。(4)この期間中の実死亡者は 1 名 （５3才、男、契約 2 年 11 ケ月後虚血性心疾忠にて
死亡)であった。(5)従って算出された死亡指数は 79.6 であた。

調查 II：(1)対象 291 名の 8 年間の経過契約件数は 798.2 件であった。(2)実死亡者は 1 名であった (死因不明)。(3)算出された死亡指数は29であ った。

\section{考案〜結論}

今回、生命保険会社資料を基にW P W 症候群の 自然歴をみようとしたが、平均観察期間（即ち 平均有効契約期間) は 3 年前後で長期観察は困難 であり、又統計資料が中心であるので一例、一例 の追跡は不可能であった。かかる制限はあるもの の、今回の調査ではW P W 症候群の算出死亡指数 は 100 以下で、少くも一般健常者より死亡の機会 が多いとは思えなかった。 
WPW 症候群の診断と治療

小児科領域の特異性

新村一郎, 原口寿夫

横浜市立大学病院小児科

I. Niimura, H. Haraguchi

Dept. of Pediatrics, Yokohama City University Hospital

小児期 W P W 症候群の臨床像に関してはなお不 明な点が多い。そこで, 演者らは小児期の上室性 頻拍（ S V T ）飞占めるW P W 比率, リエント

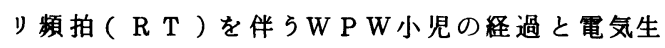
理学的所見, さらに心满病検診で偶然に検出され たW P W小児の長期観察について検討した。

$\mathrm{S} V \mathrm{~T}$ の年龄分布（図1）：乳児期には異所性 心房性頻拍（EA T ）が 46 \%と優位であったが, 学童期に入ると W P Wが首位を占め, E A T と他 の R T は同率の 2 位となった。乳児期発症の W P $\mathrm{W} 9$ 例中 $\mathrm{A}$ 型は 6 例で, 全例幼児期にはデルタ波 の消失と共に頻拍の終止をみた。B型 3 例中 2 例 す経過中にデルタ波は消失し, 1 例のみが頻拍発 作を持続した。次に，学童期に頻拍を初発した 30 例についてみると, 右側副层導路は 27 例と圧倒的 多数を占めた。 30 例中初診時に要治療は 18 例で, その内 10 例は経過中に頻拍は終止した。一方, 初 診時に筸治療は 14 例で, その内 2 例は経過中に治 療を必要とした。

電気生理学的検査：副云導路を順行云導する1 例を除いた 13 例の副云導路順行层導 E R P は 299

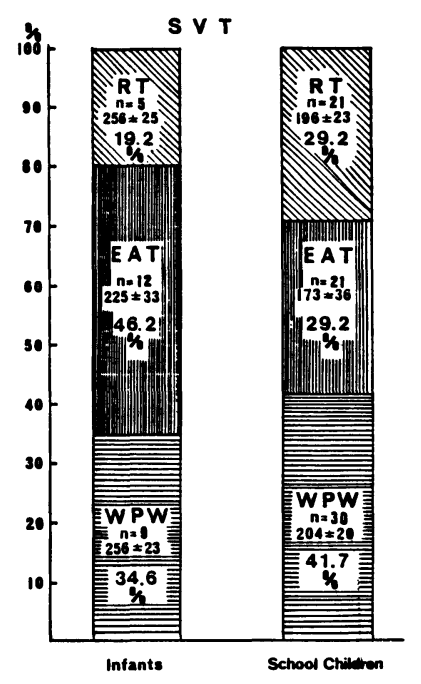

士23msec, 逆行云尊 E R P $211+19 \mathrm{msec}$ 後 者で著しい短縮をみた。

W P W の発生頻度 : 演者らの就学前児童心䐵検 診約 43 万人より 209 例 $(0.048 \%)$ が検出された。 この内, 10 年以上経過観察の 74 例についてみる

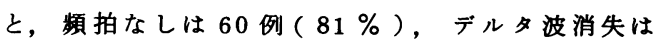
8 例 $(11 \%)$ であったのに対し，頻拍は僅かにす 6 例 $(8 \%)$ のみであり，しかも要治療は 2 例で あった（表 1 )。

結 語

1）乳児期発症例は A 型が多く，頻拍は加龄と共 に終止する傾向を示した。

2）学童期発症 30 例では逆に B 型が優位を占め, 頻拍発作は 14 例 (47\%) で継続し, その内 8 例が 治療を引続いて必要とした。

3)成人と比較して副云導路の逆行层導 E R P の 短縮をみた。

4)就学前児童における W P 発生頻度は 1 万名 につき約 5 名であった。 10 年以上の長期観察では 頻拍発作をみないW P W は全体の $81 \%$,デルタ波 消失は $11 \%$, 経過中に頻拍発作を呈した症例は 8 \%であった。 
内科的療法とその限界

伊藤明一*篠田晋*長島道夫*

*仙台市立病院内科

M. Ito *; S. Shinoda * M. Nagashima*

* Dept. of Internal Medicine, Sendai City Hospital

WPW 症候群は, 近年の診断技術の向上と外科的 治療の登場により，さらに詳細に検討されるよう になった。臨床心䑏電気生理学的検査の臨床応用 は, 潜在性WPW 症候群の診断と治療の両面での重 要性を明らかにした。WPW症候群の治㩧を適切に 行うためには，その臨床像を正確に把暒するとと が重要である。そこで,WPW症候群の臨床像と治 療法について分析し, 内科的療法の限界について 考察した。

1. 対象および方法

158 (男 97 , 女 $61 ， \mathbf{A}$ 型 61， B 型 64， A 型+ B 型 1 , 分類不能 6 , 潜在性 26 ) 例のWPW症候群を対 象として，その臨床像と治瘦法について検討を加 えた。初診時の年令は $0 \sim 74$ (平均 38.6 ) 歳で, 経過観察期間は 1 日〜 12 年 (平均 4 年 5 ケ月) で ある。うち 117 例に臨床心䑏毠気生理学的検査を 施行した。

2. 結果

不整脈の種類：158 例中 117 例で影拍発作が疑 われる症状かみられ，うち97 例で頉拍性不整脈を 心電困で確認しえた。発作性上室性頖拍 (PSVT) か 87 例（90\%）と最も多く，心房粗細動( A F ) が 36 例 ( 37 \%) に, 洞停止が 4 例に，心室性頻拍 が 2 例に，心室細動が 1 例に証められた。なお 26 例（ 27 g ）は, PSVT とAFの両者を有した。

臨床心㙖電気生理学的検查: 82 例では, PSVT 興蒿旋回路の逆伝導路としてKent束が関与してい た。2 例が房室結節内リエントリーによるPSVT， 1 例が洞結節リエントリーによるPSVTを示した。

予防的治療：頉拍発作を有する 117 例中， 59 例 ( 50 9 ) は予防的治瘦を必要とせず， 8 例は発作 時のみ服薬した。39例( $33 \%$ )に継続的投薬を， 4 例にVVIペースメーカー植込みと䔞物度法の併用 を，1例に誘導型ペースメ一カー植込みを，6 例 に手術を行った。

頖拍発作の出現頛度：日 1 回以上の 14 例中 12 例 $(86 \%)$,月 1 回以上の 39 例中 25 例 $(64 \%)$, 年 1
回以上の 44 例中 21 例 $(48 \%)$, 年 1 回末满の 20 例中 0 名で予防的治療を必要とした。

頻拍発作の持続時間： 1 時間以内の 52 例中 $15 \%$, 6 時間以内の 35 例中 25 例 ( $71 \%)$ ， それ以上持続し た30例中 25 例 (83 \%) で予防的治療を行った。

頻拍発作時の症状: 呼吸困難は27\%，胸痛は 22 \%,失神は14 \%の例にみられた。これらの症状を 有する例で，予防的治療をより必要とした。

頻拍発作時の処置：発作時薬物療法を必要とし た39例中 85 名で，予防的治療が行われた。

ペースメーカ一植込み：薬物療法を併用した 4 例全例は，PSVTとAFのほかに洞停止も有していた。

手術： 6 例 ( 4 例でKent 束切断術)で試みられ た。4例は颊拍発作時合併心疾患により心不全症 状か増悪したため，1例は薬物療法が十分な勃果 を示さなかったため，手術適応と考えられた。

死亡：経過観察中死亡した 8 例中 2 例は, 不整 脈によると思われる突然死であった。

3. 考案および結語

WPW 症候群の臨床像はきわめて多彩である。す なわち，全く治療を必要としない症例から，突然 死をきたす症例まで幅広く存在する。従って，個々 の症例において適切な治療法を選択するにあたっ ては，以下の諸点について検討を加えなりればな らない。まず問診により，頉拍発作の出現顆度や 持続時間，発作時の症状などを詳細に分析する。 ついで，心電困モ二タ一で症状出現時の心電図記 録に努めるとともに, 臨床心腆电気生理学的検査 を行い，不整脈の種類や機序を正碓に診断し，薬 物や電気刺擞に対する反応を検討しなりればなら ない。さらに頻拍発作の停止の櫵易度，薬物療法 の有用性，合併心疾患，患者の社会的状况などを あ考虑すべきである。このような種々の因子を分 析した上で，内科的廉法の限界は総合的に决定さ れなりればならない。 
複数バイパス例の診断と治療

三崎拓郎 向井恵一 三井 毅 麻柄達夫 鎌田栄一郎 岩 喬 金沢大学第 1 外科

T.Misaki,K. Muka i ,T. Mitsui,T. Magara,E Kamata,T. Iwa

Dept. of 1 st Surgery,Kanazawa Univ.

W PW症候群化対して手術療法を行う際，注意 しなくてはいけないのは複数バイパス例の存在で ある。てれらの症例では，すべてのバイパスを術 前おょび術中の電気生理検査で見い出し切断する 必要がある。我々は現在までに 178 例のW P W 症 候群に対して手術療法を行つてきたが，てれらの 症例のうちの複数バィパス例に注目し珍断と治療 に関して検討を加える。

\section{1. 対象および方法}

対象は 1973 年から 1984年 7 月まで教室において 手術を行つた複数バイパス例18例である。年令は 13 才から46才（平均 27.6 才）で男女比は $15: 3$ て あつた。また 5 例に Ebstein病の合併を認めた。 術前検査として心電図，体表面電位図，カテーテ ル心内膜マッピング，心臓ペーシングを，術中検 查として心表面マッピング, 直視下心内膜マッピ ングを行い順行性わよび逆行性のバイパスを検出 した。手術は胸骨正中切開で心㖑洼し，体外循 環使用下に心房を切開し，房室弁輪部に治いバィ パス存在部の心房筋を心内膜側より離断, 再吻合 する方法で行つた。

\section{2 . 結果}

表 1 亿18例の結果を示す。全例 2 本のバイパ スを有し，35本がAtrioventricularバイパス， 残りの 1 本が Nodofascicular バイパスであつた。 また 2 本のバイパスは各々 6 例では同一房室弁輪 側飞、12 例では反対房室弁輪側に存在した。また 35 本の Atriovent ricular バイパスのうち潜在型が 11 本，間㰤型が 2 本，云導時間延長型が 2 本を占 めた。複数バイパス例の診断は，12 例で術前に 1 例で術中になされた。てれら13例では両バイパ スに対し一期的にバイパス切断術が行われた。残 りの 5 例では術後に 2 本目のバイパスが診断され 二期的手術を必要とした。(335本の Atrioventricular バイパスのうち 33 本が手術により完全に切断され
た。2 例で術後Wide QRS 類拍が $t$ ight QRS 類拍 となり，頻拍の頻度が著激した。(4術前 18 例中 13 例で心電図上Wide QRS 頻拍が生じた。

\section{3. 結論}

手術療法の初期例では；再手術を必要とした例 も多かつたが，術前・術中の電気生理検查の進歩 により現在では一期的複数バイパス切断術が可能 となつた。Wide QRS 類拍をみた時は複数バイパ ス例を疑うとともに, 通常の症例においても潜在 型バイパスを念頭におき術前，術中検查を行うべ きと考える。

表 1 ・複数バイパス症例

\begin{tabular}{|c|c|c|c|c|c|}
\hline \multicolumn{4}{|c|}{ 年令・性 } & バイパス 部位 & 診断時期 \\
\hline 1 & 2 & 6 & 男 & $\mathbf{R} \mathbf{P} \mathbf{W}+\mathbf{R} \mathbf{P} \mathbf{S}$ & 術後 $\rightarrow$ 再手術 \\
\hline 2 & 1 & 5 & 男 & $\mathbf{R} \mathbf{P} \mathbf{S}+\mathbf{R A} \stackrel{S}{\mathbf{x}}^{-}$ & 術中 \\
\hline 3 & 3 & 6 & 男 & $\mathbf{R} \mathbf{P} \mathbf{W}+\mathbf{R} \mathbf{A} \mathbf{W}$ & 術後 $\rightarrow$ 再手術 \\
\hline 4 & 2 & 9 & 男 & $\mathbf{R} \mathbf{A} \mathbf{W}+\mathbf{R} \mathbf{A} \mathbf{S}$ & 術後 $\rightarrow$ 再手術 \\
\hline 5 & 1 & 8 & 男 & $\mathbf{L} \mathbf{P}+\mathbf{R} \mathbf{A} \mathbf{S}$ & 術後 $\rightarrow$ 再手術 \\
\hline 6 & 1 & 5 & 男 & $R \mathbf{L} \mathbf{W}+\mathbf{L} \mathbf{L}$ & 術前 \\
\hline 7 & 2 & 4 & 男 & $\mathbf{R} \mathbf{A} \mathbf{W}+\mathbf{L} \mathbf{L} \mathbf{W}$ & 術前 \\
\hline 8 & 1 & 3 & 男 & $R \mathbf{L} \mathbf{W}+\mathbf{L} \mathbf{L}$ & 術前 \\
\hline 9 & 2 & 8 & 女 & RL W W & 術前 \\
\hline 10 & 3 & 2 & 男 & $R \mathbf{L} \mathbf{W}+\mathbf{L} \mathbf{L} \underset{\mathbf{w}}{*}$ & 術前 \\
\hline 11 & 4 & 6 & 女 & $\mathbf{L A W}+\mathbf{R A} \stackrel{\leftrightarrow}{\mathbf{S}^{\circ}}$ & 術前 \\
\hline 12 & 2 & 4 & 男 & $\mathbf{R} \mathbf{P} \mathbf{W}+\mathbf{L} \mathbf{L}$ & 術前 \\
\hline 13 & 3 & 0 & 男 & $L \mathbf{L} \mathbf{W}+\mathbf{R} \mathbf{L}$ & 術前 \\
\hline 14 & 4 & 0 & 男 & 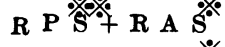 & 術前 \\
\hline 15 & 3 & 2 & 男 & $\mathbf{R} \mathbf{L} \mathbf{W}+\mathbf{L} \mathbf{L} \underset{\mathbf{w}}{\mathbf{W}}$ & 術前 \\
\hline 16 & 3 & 9 & 男 & RL L & 術前 \\
\hline 17 & 1 & 6 & 女 & $\mathbf{R} \mathbf{P} \mathbf{S}+\mathbf{L} \mathbf{L} \mathbf{W}$ & 術後 $\rightarrow$ 再手術 \\
\hline 18 & 3 & 4 & 男 & $\mathbf{R} \mathbf{P} \mathbf{W}+\mathbf{N} \mathbf{F}$ & 術前 \\
\hline
\end{tabular}

$※=$ 潜在型，※※= Slow conduct ion $※ ※ \%=$ 間次型 